\title{
Association of Genetic Polymorphisms of IFNGR1 with the Risk of Pulmonary Tuberculosis in Zahedan, Southeast Iran
}

\author{
Mohammad Naderi, ${ }^{1}$ Mohammad Hashemi, ${ }^{2,3}$ Maryam Rezaei, ${ }^{3}$ and Abolhassan Safdari ${ }^{1}$ \\ ${ }^{1}$ Infectious Diseases and Tropical Medicine Research Center, Zahedan University of Medical Sciences, Zahedan 43181-98167, Iran \\ ${ }^{2}$ Cellular and Molecular Research Center, Zahedan University of Medical Sciences, Zahedan 43181-98167, Iran \\ ${ }^{3}$ Department of Clinical Biochemistry, School of Medicine, Zahedan University of Medical Sciences, Zahedan 43181-98167, Iran
}

Correspondence should be addressed to Mohammad Hashemi; mhd.hashemi@gmail.com

Received 12 October 2015; Accepted 27 October 2015

Academic Editor: Alexander S. Apt

Copyright (C) 2015 Mohammad Naderi et al. This is an open access article distributed under the Creative Commons Attribution License, which permits unrestricted use, distribution, and reproduction in any medium, provided the original work is properly cited.

\begin{abstract}
Aim. The present study was undertaken to find out the possible association between interferon-gamma (IFN- $\gamma$ ) receptor 1 (IFNGR1) gene polymorphisms and risk of pulmonary tuberculosis (PTB) in a sample of Iranian population. Methods. Polymorphisms of IFNGR1 rs1327474 (-611 A/G), rs11914 (+189 T/G), rs7749390 (+95 C/T), and rs137854905 (27-bp ins/del) were determined in 173 PTB patients and 164 healthy subjects. Results. Our findings showed that rs11914 TG genotypes decreased the risk of PTB in comparison with TT $(\mathrm{OR}=0.36,95 \% \mathrm{CI}=0.21-0.62$, and $p=0.0002)$. The rs11914 G allele decreased the risk of PTB compared with T allele ( $\mathrm{OR}=0.41,95 \% \mathrm{CI}=0.25-0.68$, and $p=0.0006)$. IFNGR1 rs7749390 CT genotype decreased the risk of PTB in comparison with CC genotype $(\mathrm{OR}=0.55,95 \% \mathrm{CI}=0.32-0.95$, and $p=0.038)$. No significant association was found between IFNGR1 rs1327474 A/G polymorphism and risk/protective of PTB. The rs137854905 (27-bp I/D) variant was not polymorphic in our population. Conclusion. Our findings showed that IFNGR1 rs11914 and rs7749390 variants decreased the risk of PTB susceptibility in our population.
\end{abstract}

\section{Introduction}

Tuberculosis is an infectious disease and remains a major public health problem as well as leading cause of morbidity and mortality worldwide mostly in Asia and Africa [1,2]. According to the annual report on global control of TB from WHO, approximately 8.6 million new cases occurred in 2012 [3]. It has been expected that one-third of population is infected with TB, while $5-10 \%$ of infected cases will develop active TB during their lifetimes [3], which suggests a role of genetic variation in host immunity. It was expected that the impact of genetic factors on the phenotypic variation and immune responses in the population infected with TB ranges up to $71 \%[4]$.

Up to now, we have shown evidence of association between host genetic polymorphisms and PTB susceptibility, including interferon-gamma (IFNG) [5], MIF [6], TLR2 [7], IRGM [8], TIRAP [7], and CD209 [9] in a sample of Iranian population.
IFNG and its receptor (IFNGR1) are key components of innate and adaptive immunity and have been involved in a wide range of infectious and inflammatory disease processes. The IFNG gene has beneficial effects on microbial killing and potentially deleterious consequences $[10,11]$. IFNG signaling is mediated through the ligand binding to IFNGR1. Control of IFNGR1 expression level is one of the mechanisms by which cells modulate the potency of IFNG signaling [12]. The receptor for IFNG is made up of $\alpha$ and $\beta$ subunits, both of which are integral membrane proteins. The $\alpha$ subunit (encoded by the gene IFNGR1) plays a critical role in ligand binding, receptor trafficking, and signal transduction [13]. The human receptor of IFNG (IFNGR) is a heterodimer of IFNGR1 and IFNGR2. The IFNGR1 gene is located on the long arm of chromosome 6 at position 23.3 (6q23.3), which encodes the ligand binding chain (alpha) of the interferon-gamma receptor. Defects in IFNGR1 have been reported as a cause of Mendelian susceptibility to mycobacterial disease, also known as familial disseminated atypical mycobacterial infection [14]. 
TABLE 1: Primers sequences used for detection of INFGR1 gene polymorphisms.

\begin{tabular}{|c|c|c|c|c|}
\hline $\begin{array}{l}\text { INFGR1 } \\
\text { polymorphisms }\end{array}$ & Sequence $\left(5^{\prime} \rightarrow 3^{\prime}\right)$ & Restriction enzyme & Product size (bp) & $\begin{array}{c}\text { Annealing } \\
\text { temperature }\left({ }^{\circ} \mathrm{C}\right) \\
\end{array}$ \\
\hline \multirow{2}{*}{$\begin{array}{l}\mathrm{rs} 1327474 \\
(-611 \mathrm{~A} / \mathrm{G})\end{array}$} & F: AGAGCAGACCTCTTCATGAGAGGCTGTCT & \multirow{2}{*}{ Hpy188I } & \multirow{2}{*}{$\begin{array}{l}\text { G allele: } 204,29 \\
\text { A allele: } 233\end{array}$} & \multirow{2}{*}{63} \\
\hline & R: ACATTTTTAGAAGAGAATGAGACTTCAAA & & & \\
\hline \multirow{2}{*}{$\begin{array}{l}\text { rs11914 } \\
(+189 \mathrm{~T} / \mathrm{G})\end{array}$} & F: GCCATTTGGTGGTCCATTAC & \multirow{2}{*}{ TaqI } & \multirow{2}{*}{$\begin{array}{l}\text { G allele: } 286,210 \\
\text { T allele: } 496\end{array}$} & \multirow{2}{*}{64} \\
\hline & R: TCCAGACAGCTGGAATCAGT & & & \\
\hline \multirow{2}{*}{$\begin{array}{l}\text { rs7749390 } \\
(+95 \mathrm{C} / \mathrm{T})\end{array}$} & F: CTCTTTCTCCTACCССTTGTCAT & \multirow{2}{*}{ BstC8I } & \multirow{2}{*}{$\begin{array}{l}\text { C allele: } 87,121 \text {, and } 158 \\
\text { T allele: } 208,158\end{array}$} & \multirow{2}{*}{62} \\
\hline & R: CAGCGCATAATCGTATTTAAAAGTG & & & \\
\hline \multirow{2}{*}{$\begin{array}{l}\text { rs137854905 } \\
(27-b p ~ I / D)\end{array}$} & F: GCAGCCATCTGACTCCAATAG & \multirow{2}{*}{-} & \multirow{2}{*}{$\begin{array}{l}\text { I allele: } 223 \\
\text { D allele: } 196\end{array}$} & \multirow{2}{*}{67} \\
\hline & R: TTTGGGGGAAATTCTGAGTC & & & \\
\hline
\end{tabular}

Several potentially functional single nucleotide polymorphisms (SNPs) have been identified in the human IFNGR1 gene. Few studies investigated the association between IFNGR1 gene polymorphisms and risk of TB [15-17]. To the best of our knowledge there is not any report regarding the possible association between IFNGR1 polymorphisms and PTB risk of Iranian population. Thus, the present study aimed to examine the possible associations between polymorphisms of IFNGR1 gene and susceptibility to PTB in sample of Iranian population.

\section{Materials and Methods}

2.1. Study Population. This case-control study was done on 173 PTB patients and 163 healthy subjects. The enrollment process and study design are described elsewhere previously $[6,9,18]$. Briefly, diagnosis of PTB was based on clinical symptoms, radiological evidence, and bacteriological investigations such as sputum Acid Fast Bacillus (AFB) smear positivity, culture, and response to antituberculosis chemotherapy. All control subjects were unrelated adults selected through the population without recent sign, symptom, or history of TB and from the same geographical origin, as the patients with PTB.

The local ethics committee of the Zahedan University of Medical Sciences approved the project, and informed consent was obtained from all individual participants included in the study. Genomic DNA was extracted from the whole blood by the salting out method.

2.2. Genotyping. The genotyping of IFNGR1 rs1327474, rs11914, and rs7749390 polymorphisms was done by PCRRFLP method. The 27-bp I/D variant was genotyped by PCR methods. The primer sequences with respective annealing temperatures and their amplicon sizes were shown in Table 1.

In each $0.20 \mathrm{~mL}$ PCR reaction tube, $1 \mu \mathrm{L}$ of genomic DNA ( $100 \mathrm{ng} / \mathrm{mL}), 1 \mu \mathrm{L}$ of each primer, and $10 \mu \mathrm{L}$ of $2 X$ Prime Taq Premix (Genet Bio, Korea) and the appropriate amount of ddH2O were added.

The PCR cycling conditions for SNPs were the initial denaturation at $95^{\circ} \mathrm{C}$ for $5 \mathrm{~min}$ followed by 30 cycles for $30 \mathrm{~s}$ at $95^{\circ} \mathrm{C}$ and annealing temperature (Table 1) for $30 \mathrm{~s}$ and extension at $72^{\circ} \mathrm{C}$ for $30 \mathrm{~s}$, with a final extension of $72^{\circ} \mathrm{C}$ for

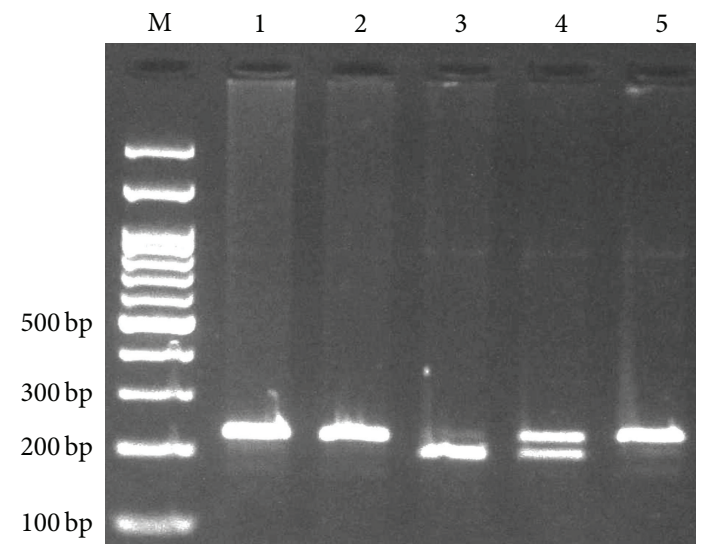

FIGURE 1: Electrophoresis pattern of polymerase chain reaction restriction fragments length polymorphism (PCR-RFLP) for detection of IFNGR1 rs1327474 polymorphism. G allele digested by Hpy188I restriction enzyme and produces 204 and 29 bp while A allele undigested (233 bp). M: DNA marker; lanes 1, 2, and 5: AA; lane 3: GG; lane 4: AG.

$10 \mathrm{~min}$. The PCR products were verified onto $2.5 \%$ agarose gels containing $0.5 \mu \mathrm{g} / \mathrm{mL}$ ethidium bromide and observed under UV light (Figures 1, 2, 3, and 4).

2.3. Statistical Analysis. Analysis of the data was done using the SPSS 18.0 software. The differences between the variables were evaluated by chi-square test or independent sample $t$ test according to the data. The associations between genotypes and PTB were calculated by computing the odds ratio (OR) and 95\% confidence intervals (95\% CI) from logistic regression analyses. $p$ value less than 0.05 was considered statistically significant.

\section{Results}

The study consisted of 173 PTB (64 males and 109 females; ages $50.1 \pm 20.6$ years) patients and 164 healthy subjects (70 males and 94 females; ages $47.5 \pm 15.3$ years). There was no significant difference between the groups concerning sex and age $(p>0.05)$. 


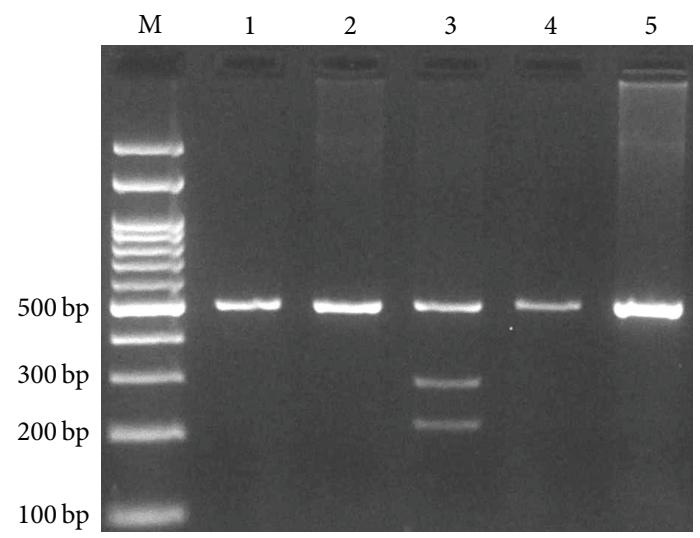

FIGURE 2: Electrophoresis pattern of PCR-RFLP for detection of IFNGR1 rs11914 polymorphism. G allele digested by TaqI restriction enzyme and produces 286 and $210 \mathrm{bp}$ while the T allele undigested (496 bp). M: DNA marker; lanes 1, 2, 4, and 5: TT; lane 3: TG.

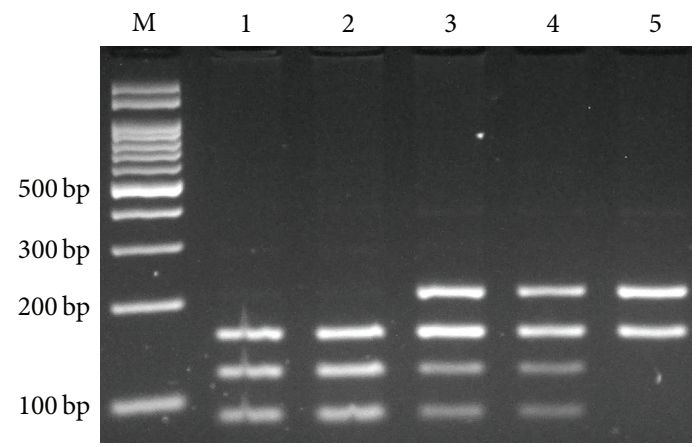

FIGURE 3: Electrophoresis pattern of PCR-RFLP for detection of IFNGR1 rs7749390 polymorphism. The 366-bp PCR product digested by BstC8I. C allele produces 87,121 , and $158 \mathrm{bp}$, while the T allele produces 208 and $158 \mathrm{bp}$. M: DNA marker; lanes 1 and 2: CC; lanes 3 and 4: CT; Lane 5: TT.

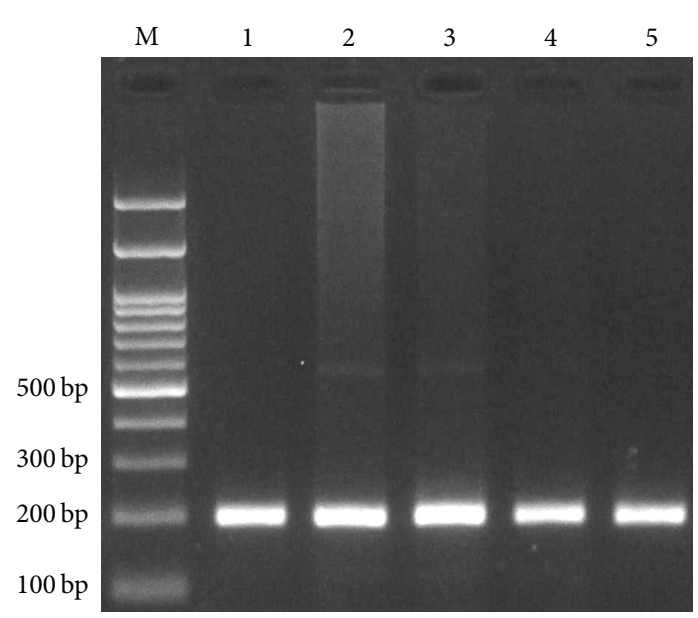

FIGURE 4: Electrophoresis pattern of PCR for detection of IFNGR1 rs137854905 (27-bp I/D) polymorphism. I allele produces $223 \mathrm{bp}$ while D allele produces $196 \mathrm{bp}$. M: DNA marker; lanes 1, 2, 3, 4, and 5: DD.
TABLE 2: Frequency distribution of INFGRI gene polymorphisms in PTB and control subjects.

\begin{tabular}{|c|c|c|c|c|}
\hline $\begin{array}{l}\text { Gene } \\
\text { polymorphisms }\end{array}$ & $\begin{array}{l}\text { PTB } \\
n(\%)\end{array}$ & $\begin{array}{c}\text { Controls } \\
n(\%)\end{array}$ & OR (95\% CI) & $p$ \\
\hline \multicolumn{5}{|l|}{$\begin{array}{l}\text { rs1327474 } \\
(-611 \mathrm{~A} / \mathrm{G})\end{array}$} \\
\hline AA & $56(32.4)$ & $63(38.4)$ & 1.00 & - \\
\hline AG & $105(60.7)$ & $94(57.3)$ & $1.26(0.79-1.98)$ & 0.354 \\
\hline GG & $12(6.9)$ & $7(4.3)$ & $1.93(0.71-5.24)$ & 0.223 \\
\hline \multicolumn{5}{|l|}{ Allele } \\
\hline A & $217(62.7)$ & $220(67.1)$ & 1.00 & - \\
\hline G & $129(37.3)$ & $108(32.9)$ & $1.21(0.88-1.66)$ & 0.258 \\
\hline \multicolumn{5}{|l|}{$\begin{array}{l}\text { rs11914 } \\
(+189 \mathrm{~T} / \mathrm{G})\end{array}$} \\
\hline $\mathrm{TT}$ & $148(85.5)$ & $112(68.3)$ & 1.0 & - \\
\hline TG & $25(14.5)$ & $52(31.7)$ & $0.36(0.21-0.62)$ & 0.0002 \\
\hline GG & $0(0.0)$ & $0(0.0)$ & - & - \\
\hline \multicolumn{5}{|l|}{ Allele } \\
\hline $\mathrm{T}$ & $321(92.8)$ & $276(84.1)$ & 1.00 & - \\
\hline G & $25(7.2)$ & $52(15.9)$ & $0.41(0.25-0.68)$ & 0.0006 \\
\hline \multicolumn{5}{|l|}{$\begin{array}{l}\text { rs7749390 } \\
(+95 \mathrm{C} / \mathrm{T})\end{array}$} \\
\hline CC & $48(27.7)$ & $34(20.7)$ & 1.00 & - \\
\hline $\mathrm{CT}$ & $63(36.4)$ & $81(49.4)$ & $0.55(0.32-0.95)$ & 0.038 \\
\hline $\mathrm{TT}$ & $62(35.8)$ & 49 (29.9) & $0.88(0.49-1.57)$ & 0.768 \\
\hline \multicolumn{5}{|l|}{ Allele } \\
\hline C & $159(45.9)$ & $149(45.4)$ & 1.00 & - \\
\hline $\mathrm{T}$ & $187(54.1)$ & $179(54.6)$ & $0.98(0.72-1.33)$ & 0.938 \\
\hline \multicolumn{5}{|l|}{$\begin{array}{l}\text { rs137854905 } \\
(27-b p ~ I / D)\end{array}$} \\
\hline $\mathrm{DD}$ & $173(100)$ & $164(100)$ & - & - \\
\hline ID & $0(0.0)$ & $0(0.0)$ & - & - \\
\hline II & $0(0.0)$ & $0(0.0)$ & - & - \\
\hline \multicolumn{5}{|l|}{ Allele } \\
\hline $\mathrm{D}$ & $346(100)$ & $328(100)$ & - & - \\
\hline I & $0(0.0)$ & $0(0.0)$ & - & - \\
\hline
\end{tabular}

Genotypes and allele frequencies of IFNGR1 polymorphisms are shown in Table 2.

Our findings indicated that rs11914 TG genotypes decreased the risk of PTB in comparison with TT $(\mathrm{OR}=$ $0.36,95 \% \mathrm{CI}=0.21-0.62$, and $p=0.0002$ ). In addition, the rs11914 $\mathrm{G}$ allele decreased the risk of PTB in comparison with $\mathrm{T}$ allele (OR $=0.41,95 \% \mathrm{CI}=0.25-0.68$, and $p=0.0006)$. Regarding IFNGR1 rs7749390 variant, the CT genotype decreased the risk of PTB in comparison with CC genotype $(\mathrm{OR}=0.55,95 \% \mathrm{CI}=0.32-0.95$, and $p=0.038)$. IFNGR1 rs7749390 T allele was not associated with PTB risk.

No significant association was observed between IFNGRI rs1327474 polymorphism and risk/protective of PTB. We found that rs137854905 (27-bp I/D) variant was not polymorphic in our population. 


\section{Discussion}

The clinical outcome of TB infection varies noticeably among individuals. Host immunity and genetic factors may be involved in susceptibility or resistance to TB. It is believed generally that IFNG plays a key role in the pathogenesis of tuberculosis [19]. Individuals with inherited disorders of IFNG mediated immunity appear to be specifically vulnerable to TB infections [20]. It has been proposed that IFNG can activate murine macrophages to inhibit $M$. tuberculosis growth [21]. During TB infection, IFNG is upregulated and secreted as a main cytokine to activate macrophages [22]. Defects in human IFNGR1 have been shown to be associated with dominant susceptibility to mycobacterial infection [14]. Our previous study indicated an association between IFNG $+874 \mathrm{~T} / \mathrm{A}$ polymorphism and susceptibility to PTB [5]. In the present study we examined the possible association between IFNGR1 gene polymorphisms and the risk of PTB in a sample of Iranian population. We found that rs11914 TG genotype as well as G allele significantly decreased the risk of PTB. Concerning IFNGR1 rs7749390 polymorphism, we found that CT genotype decreased the risk of PTB in comparison with CC genotype. The rs1327474 A/G as well as rs137854905 (27-bp I/D) variant of IFNGR1 polymorphism was not associated with risk/protective of PTB $(p>0.05)$.

Lü et al. [16] showed that rs2234711, rs1327475, and rs7749390 polymorphisms of IFNGR1 gene were significantly associated with the altered risks of TB. The rs2234711 and rs7749390 polymorphisms decreased the risk of TB, while the rs1327475 variant increased the risk of PTB. They found no significant association among rs3799488 and rs9376267 polymorphisms and risk of PTB.

Bulat-Kardum et al. [15] investigated IFNGR1 -611 G/A and $-56 \mathrm{~T} / \mathrm{C}$ gene promoter polymorphisms in TB patients and found no significant association between the variants and TB risk in Croatian population. He et al. [17] have found a significant association between IFNGR1 rs7749390 polymorphism and TB in Chinese Han population.

The discrepancy between studies regarding the impact of IFNGR1 polymorphisms on PTB risk may be due to the phenotype definition both in cases and in controls, population genetic factors, and even potential global differences in $M$. tuberculosis strain.

In summary, our finding emphasizes the impact of IFNGR1 polymorphisms on PTB risk in a sample of Iranian population. Further studies with larger sample sizes and different ethnicities are warranted to confirm these findings.

\section{Conflict of Interests}

All authors declare that they have no conflict of interests.

\section{Acknowledgments}

This work was funded by a research grant from Zahedan University of Medical Sciences. The authors thank the patients and healthy subjects who willingly participated in the study.

\section{References}

[1] P. G. Lin and J. L. Flynn, "Understanding latent tuberculosis: a moving target," Journal of Immunology, vol. 185, no. 1, pp. 15-22, 2010.

[2] O. Oxlade, K. Schwartzman, M. A. Behr et al., "Global tuberculosis trends: a reflection of changes in tuberculosis control or in population health?" International Journal of Tuberculosis and Lung Disease, vol. 13, no. 10, pp. 1238-1246, 2009.

[3] A. Zumla, A. George, and V. Sharma, "WHO's 2013 global report on tuberculosis: successes, threats, and opportunities," The Lancet, vol. 382, no. 9907, pp. 1765-1767, 2013.

[4] M. Möller and E. G. Hoal, "Current findings, challenges and novel approaches in human genetic susceptibility to tuberculosis," Tuberculosis, vol. 90, no. 2, pp. 71-83, 2010.

[5] M. Hashemi, B. Sharifi-Mood, M. Nezamdoost et al., "Functional polymorphism of interferon- $\gamma($ IFN- $\gamma)$ gene +874 T/A polymorphism is associated with pulmonary tuberculosis in Zahedan, Southeast Iran," Prague Medical Report, vol. 112, no. 1, pp. 38-43, 2011.

[6] M. Hashemi, B. Sharifi-Mood, A. Rasouli, S. Amininia, M. Naderi, and M. Taheri, "Macrophage migration inhibitory factor-173 G/C polymorphism is associated with an increased risk of pulmonary tuberculosis in Zahedan, Southeast Iran," EXCLI Journal, vol. 14, pp. 117-122, 2015.

[7] M. Naderi, M. Hashemi, L. Hazire-Yazdi et al., "Association between toll-like receptor2 Arg677Trp and 597T/C gene polymorphisms and pulmonary tuberculosis in Zahedan, Southeast Iran," The Brazilian Journal of Infectious Diseases, vol. 17, no. 5, pp. 516-520, 2013.

[8] G. Bahari, M. Hashemi, M. Taheri, M. Naderi, E. EskandariNasab, and M. Atabaki, "Association of IRGM polymorphisms and susceptibility to pulmonary tuberculosis in Zahedan, Southeast Iran," The Scientific World Journal, vol. 2012, Article ID 950801, 5 pages, 2012.

[9] M. Naderi, M. Hashemi, M. Taheri, H. Pesarakli, E. EskandariNasab, and G. Bahari, "CD209 promoter-336 A/G (rs4804803) polymorphism is associated with susceptibility to pulmonary tuberculosis in Zahedan, southeast Iran," Journal of Microbiology, Immunology and Infection, vol. 47, no. 3, pp. 171-175, 2014.

[10] E. Jouanguy, S. Lamhamedi-Cherradi, F. Altare et al., "Partial interferon-gamma receptor 1 deficiency in a child with tuberculoid bacillus Calmette-Guerin infection and a sibling with clinical tuberculosis," The Journal of Clinical Investigation, vol. 100, no. 11, pp. 2658-2664, 1997.

[11] F. Altare, E. Jouanguy, S. Lamhamedi-Cherradi et al., "A causative relationship between mutant IFNgR1 alleles and impaired cellular response to IFN $\gamma$ in a compound heterozygous child," The American Journal of Human Genetics, vol. 62, no. 3, pp. 723-726, 1998.

[12] J. Zhou, D.-Q. Chen, V. K. M. Poon et al., "A regulatory polymorphism in interferon-gamma receptor 1 promoter is associated with the susceptibility to chronic hepatitis B virus infection," Immunogenetics, vol. 61, no. 6, pp. 423-430, 2009.

[13] E. A. Bach, M. Aguet, and R. D. Schreiber, “The IFN $\gamma$ receptor: a paradigm for cytokine receptor signaling," Annual Review of Immunology, vol. 15, pp. 563-591, 1997.

[14] E. Jouanguy, S. Lamhamedi-Cherradi, D. Lammas et al., "A human IFNGR1 small deletion hotspot associated with dominant susceptibility to mycobacterial infection," Nature Genetics, vol. 21 , no. 4 , pp. 370-378, 1999. 
[15] L. Bulat-Kardum, G. E. Etokebe, J. Knezevic et al., "Interferon$\gamma$ receptor-1 gene promoter polymorphisms (G-611A; T-56C) and susceptibility to tuberculosis," Scandinavian Journal of Immunology, vol. 63, no. 2, pp. 142-150, 2006.

[16] J. Lü, H. Pan, Y. Chen et al., "Genetic polymorphisms of IFNG and IFNGR1 in association with the risk of pulmonary tuberculosis," Gene, vol. 543, no. 1, pp. 140-144, 2014.

[17] J. He, J. Wang, D. Lei, and S. Ding, "Analysis of functional SNP in Ifng/Ifngrl in Chinese han population with tuberculosis," Scandinavian Journal of Immunology, vol. 71, no. 6, pp. 452-458, 2010.

[18] M. Hashemi, E. Eskandari-Nasab, A. Moazeni-Roodi, M. Naderi, B. Sharifi-Mood, and M. Taheri, "Association of CTSZ rs34069356 and MC3R rs6127698 gene polymorphisms with pulmonary tuberculosis," International Journal of Tuberculosis and Lung Disease, vol. 17, no. 9, pp. 1224-1228, 2013.

[19] T. Mogues, M. E. Goodrich, L. Ryan, R. LaCourse, and R. J. North, "The relative importance of $\mathrm{T}$ cell subsets in immunity and immunopathology of airborne Mycobacterium tuberculosis infection in mice," Journal of Experimental Medicine, vol. 193, no. 3, pp. 271-280, 2001.

[20] S. Dupuis, R. Döffinger, C. Picard et al., "Human interferon$\gamma$-mediated immunity is a genetically controlled continuous trait that determines the outcome of mycobacterial invasion," Immunological Reviews, vol. 178, pp. 129-137, 2000.

[21] S. Ehrt, D. Schnappinger, S. Bekiranov et al., "Reprogramming of the macrophage transcriptome in response to interferon- $\gamma$ and mycobacterium tuberculosis: signaling roles of nitric oxide synthase-2 and phagocyte oxidase," Journal of Experimental Medicine, vol. 194, no. 8, pp. 1123-1140, 2001.

[22] J. Lee and H. Kornfeld, "Interferon- $\gamma$ regulates the death of $M$. tuberculosis-infected macrophages," Journal of Cell Death, vol. 3, pp. 1-11, 2010. 


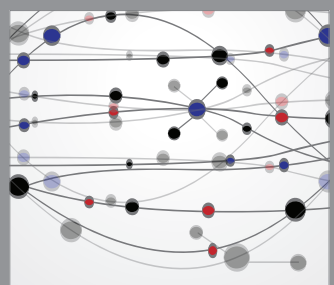

The Scientific World Journal
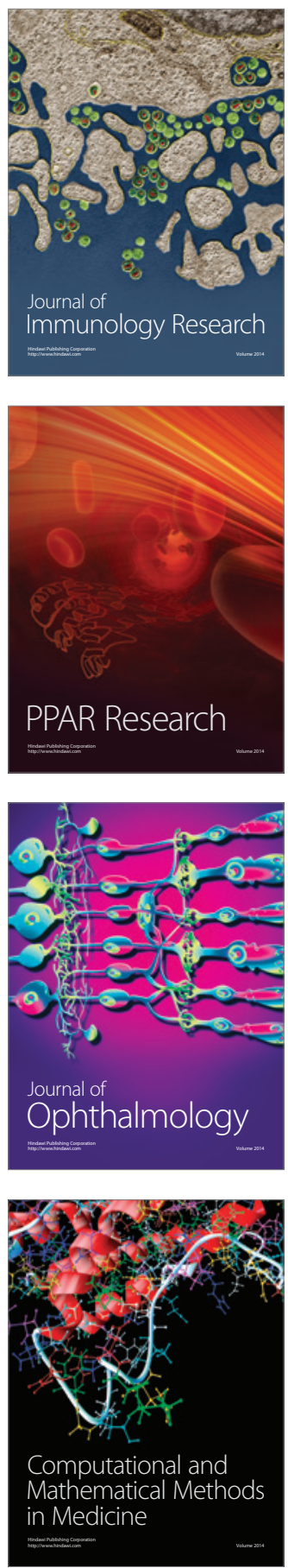

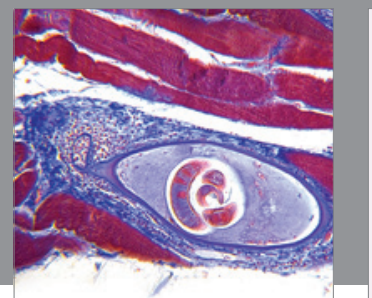

Gastroenterology

Research and Practice
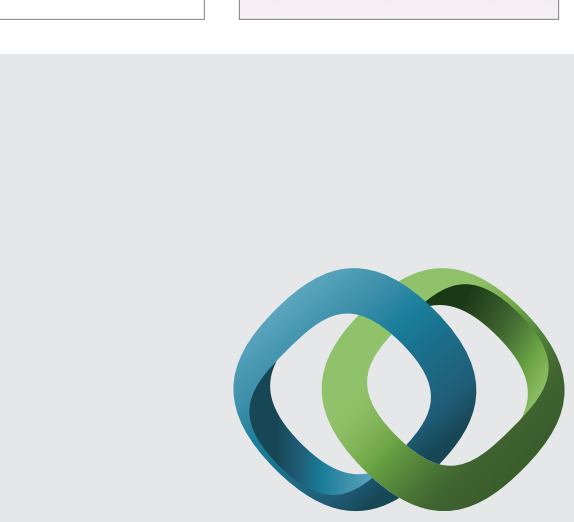

\section{Hindawi}

Submit your manuscripts at

http://www.hindawi.com
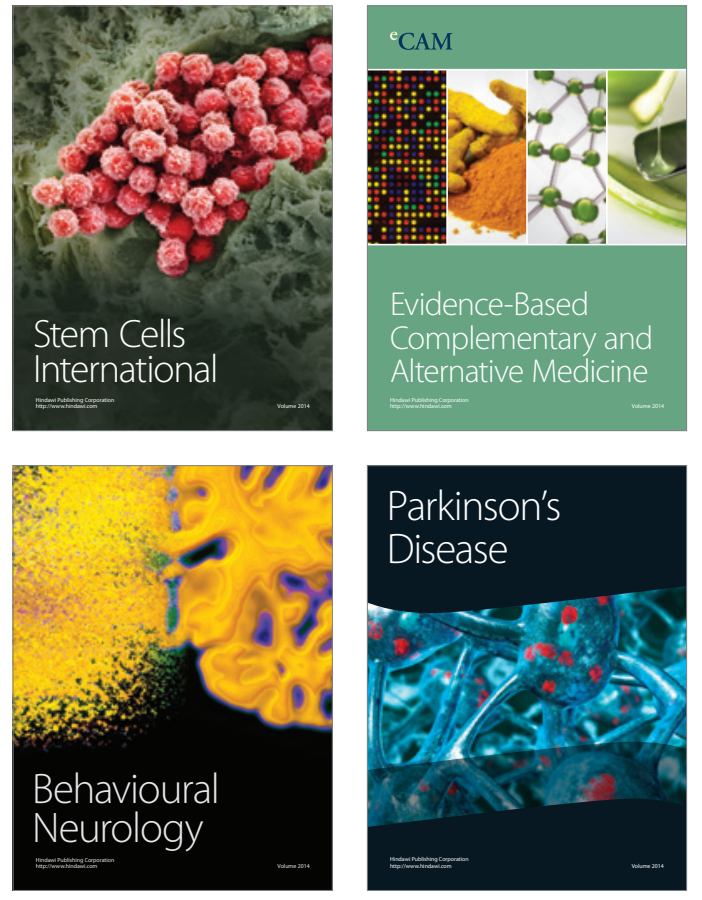
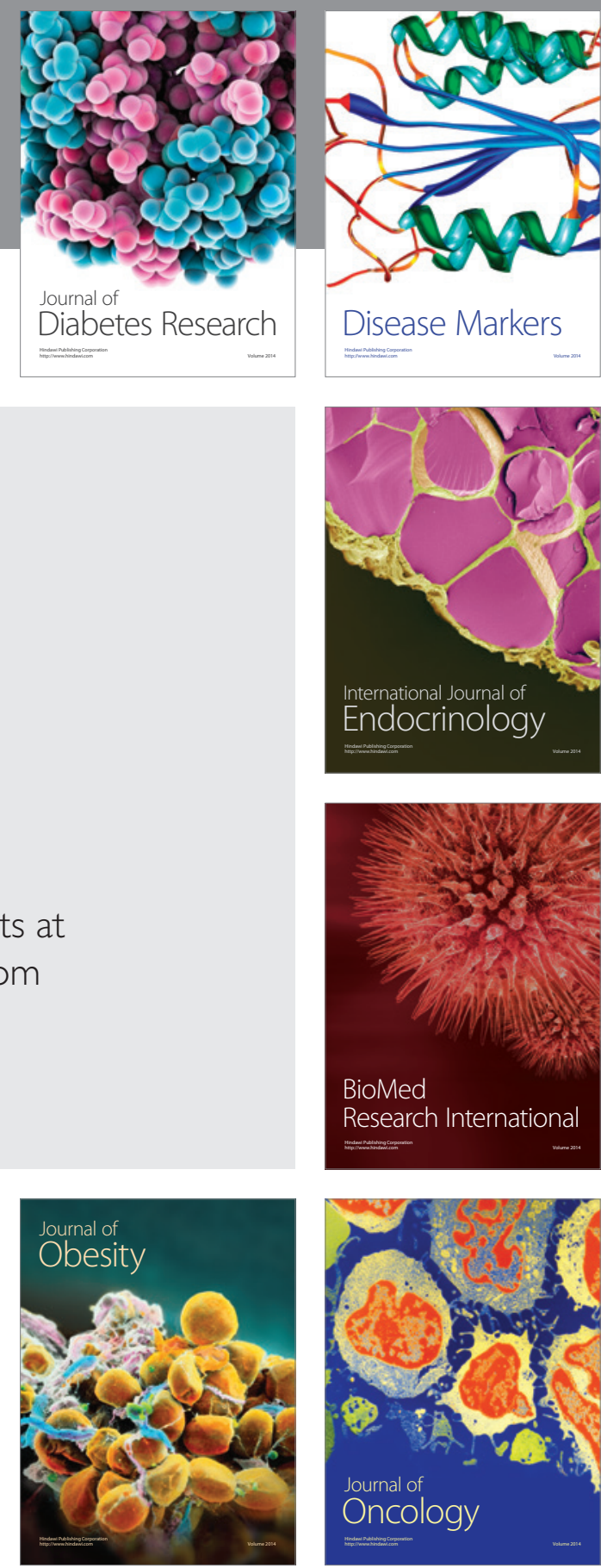

Disease Markers
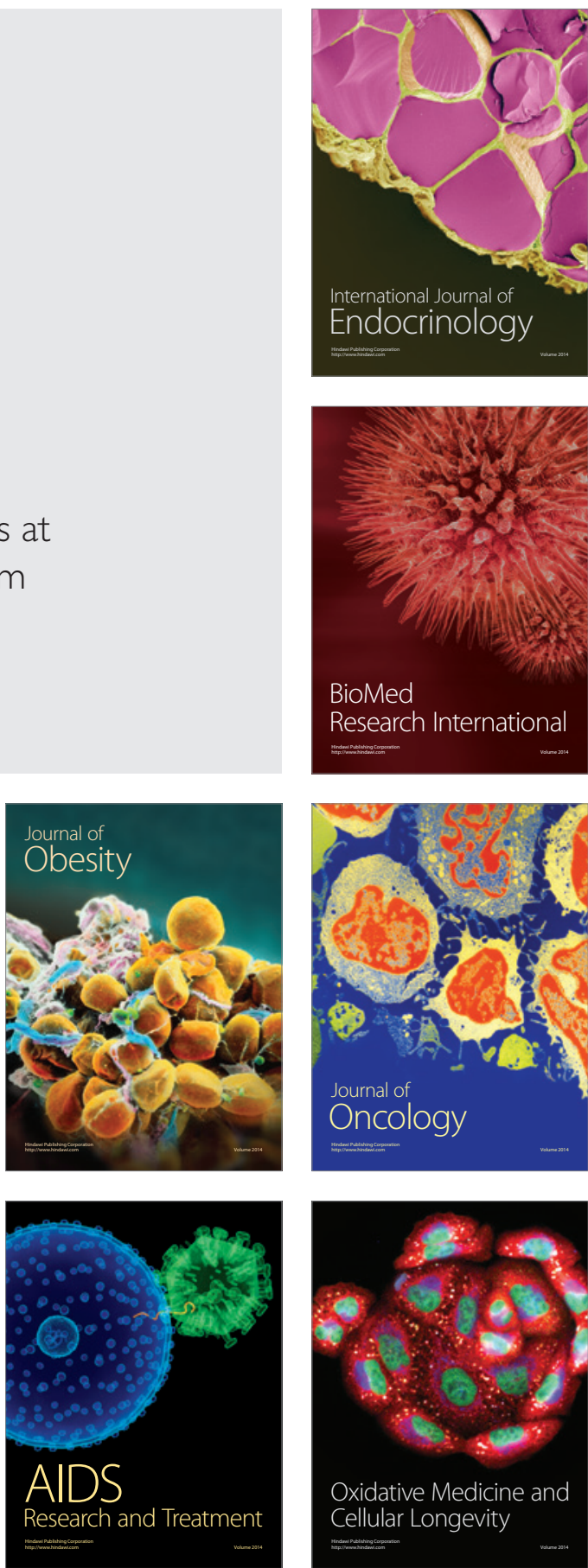